\title{
THE ROLE OF PERSISTENCE IN STUDENTS' SELF-REALIZATION
}

\begin{tabular}{l} 
Dr. Sergey I. K \\
Peoples' Friendship \\
Dr. Stanislav S. Kudinov, Chair o \\
Department, Peoples' Frien \\
Dr. Irina B. Kudinova, Chair of \\
Department, Peoples' Frien \\
Peoples' Friendship \\
Dr. Olga B. Mi \\
A R T I C L E I N F O \\
Original Research \\
Received: May, 31.2017. \\
Revised: June, 30.2017. \\
Accepted: August, 06.2017. \\
doi:10.5937/IJCRSEE1702019K \\
UDK \\
159.923.5.072 \\
159.947.5.072 \\
\hline
\end{tabular}

Keywords:

persistence, self-realization, students,

characteristics, self-expression.

\begin{abstract}
A B S T R A C T
The paper analyzes the results of an empirical research obtained with the help of a sample of students. The research of persistence was carried out within the framework of the dispositional concept of personality traits and individuality by A. I. Krupnov. The techniques developed by A. I. Krupnov as well as the author's test of persistence were used in the study. After allocating the levels of persistence, the features of self-realization were analyzed in each group of the respondents. The specificity of self-realization was revealed in the context of the author's polysystemic concept, the author's multidimensional questionnaire on personality's self-realization (MQPSR) was used as a diagnostic tool. The empirical study revealed statistically significant differences in the specifics of self-realization of the students with different levels of persistence manifestation. The respondents with a high level of persistence realize themselves more successfully in different spheres of life due to the obvious active behaviour, optimistic attitude, high motivation, creative methods and techniques of self-expression, internal self-regulation and constructive behavior. The students with low persistence lack successful self-realization because of passivity, pessimism, external locus of self-control, a high level of barriers and standard simple schemes of self-expression.
\end{abstract}

(C) 2017 IJCRSEE. All rights reserved.

\section{INTRODUCTION}

According to the numerous recent studies, self-realization not only promotes the development of professional, social and personal competencies, but also provides the level of life quality that affects all the aspects of life and human activities (Maslow, 1954; 1968; Myers, 1992; Boekaerts, 1996; Butler, 2000;

Corresponding Author

Dr. Olga B. Mikhailova, Chair of Social and Differential Psychology, Peoples' Friendship University of Russia (RUDN University), Moscow, Russia

E-mail: Olga00241@yandex.ru

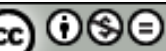

This work is licensed under a Creative Commons Attribution - NonCommercial - NoDerivs 4.0. The article is published with Open Access at www.ijcrsee.com
Dweck, 2000; Ashton and Lee, 2001; Cheng and Furnham, 2003; Chamorro-Premuzic, Furnham and Ackerman, 2006; Stee, Schmidt and Shultz 2008; Cheung, Vijver and van de, Leong, 2011; Hakimi, Hejazi and Lavasani, 2011; Zhang Ten, 2013).

Most Russian research devoted to the problem of personal self-realization deal with such problems as self-realization in the main spheres of life (Kudinov S. I., Krupnov, A. I. and Kudinov S. S., 2012) the specificity of professional self-realization (Korostyleva, 2005; Novikova, and Zamaldinova 2010; Kudinov S. I., Kudinov S. S., Mikhailova and Ruchina 2015); personal self-realization of students in their professional training Kudinov, S. I. and Kudinov, S. S., 2011; Novikova, Shlyakhta and Baranova, 2013); self-realization in mature and advanced age (Kudinov, 
2013; Mikhailova, 2015); gender stereotypes and self-realization (Zhang Ten, 2013).

In this connection there rises a question, concerning the maximum use of internal resources for a full-scale self-realization of the individual (Krupnov, Novikova and Kozhukhova, 2013). One of such resources is persistence as a personality trait, expressed in an effective upholding and advancement of the person's position, beliefs and values, and as a result, ensuring the success of his/her selfrealization in the society (Kudinov, 2013). The problem of the interdependence of selfrealization and persistence requires a careful consideration in professional training, because it is the key to a successful professionalization of the future experts at the initial stage. The data on the correlation of self-realization to persistence can be the basis for working out scientifically proved programs, the harmonization of these phenomena aiming at optimizing the vocational training of future bachelors and masters.

\section{MATERIALS AND METHODS}

The research was conducted in Moscow, Russia. 200 people participated in the pilot phase of the study, young men and girls, equal in number, 20-25 years old, the students of the Peoples' Friendship University of Russia.

In the course of the personality selfrealization diagnostics, we applied "The multidimensional questionnaire on personality self-realization" (MQPSR), the self-realization assessment express bar chart and the questionnaire "Self-estimation of personality self-realization" developed by S. I. Kudinov (Kudinov, 2013).

The multidimensional questionnaire on personality self-realization contains 16 basic scales, which characterize various aspects of the personal self-realization (social corporate self-realizing attitudes; subject-personal selfrealizing attitudes; activity; inertia; optimism; pessimism; internality; externality; socio-centralized motivation self-realization; egocentric motivation of self-fulfillment; creativity; conservatism; constructiveness; destructiveness; social barriers; personal barriers). The questionnaire includes 120 questions. The test can be used in the age group from 17 to 70 years old. Testing takes 40-50 minutes.

For studying the persistence of the person "the paper-and-pencil test of persistence" developed by A. I. Krupnov, the author's questionnaire "persistence" and "the experimental test on persistence" developed by the author were used.

The author's "experimental test of persistence" consisted of three kinds of tasks. In the first task, the respondents were given three sets of words and asked to make up three sentences. The second set of words differed from the first task by being more complex. The third set of words did not represent a possibility to make up a sentence.

Interpretation: the time spent on solving each problem was estimated. If it took twice the time to solve the third problem than to solve the first and second problems taken together, it indicated a high level of persistence. If the same amount of time was spent on solving the first two problems, it was estimated as the average level of persistence and if less than this time, then it was diagnosed as the low level of this personality trait.

The second problem was that the subjects were asked to solve three "puzzles". The time was calculated in such a way that the two of them had to be solved during the lesson in the classroom, the average solution time was 15-25 minutes for each exercise, and they had to get down to solving the third puzzle 15 minutes before the end of the lesson. After the end of the lesson, the subjects could be free or complete the puzzle.

Interpretation: The refusal to perform the second exercise was diagnosed as a low level of persistence. The refusal to do the third exercise after performing the first two exercises was regarded as the average level of persistence. Doing all the three exercises, including the last one in extracurricular time, was regarded as a high level of persistence.

The third challenge was giving the participants a set of 12 different words. It was necessary to make up several quatrains, so that all the words were used. Moreover, the fewer quatrains it took - the better. A standard assessment was three quatrains with one word per line. 30 minutes were allocated for the operation. Then additional 10 minutes were granted at the request of the participants, all in all, 30 minutes were added.

Interpretation: The refusal to continue work 30 minutes after failing to carry out the task was interpreted as the low level of persistence. 35-45 minutes spent on solving the exercises was assessed as a medium level of persistence. If carrying out the exercise took over 45 minutes, it was interpreted as the high level of persistence.

For data processing, the following methods were used: quantitative analysis us- 
ing the techniques of mathematical statistics (Kolmogorov - Smirnov's criterion, Student's t-criterion, Pearson's linear correlation coefficient, factor, variance and cluster analysis (SPSS program 11.5). Qualitative analysis of the obtained results was based on the comparison, hierarchy of expression and dominance of the structural variables of persistence and selffulfillment.

\section{RESULTS}

The results of the study of students' persistence with the help of different research methods and their subsequent quantitative and qualitative processing, allowed establishing different levels of manifestation of this personality trait in the participants. At the first stage of processing, the experiment data were analyzed, where it was required to make up three sentences from three sets of words. In the second task, the participants were asked to solve three puzzles. In the third task, it was necessary to use 12 words minimum in three quatrains, and maximum in six quatrains, the time was not limited. The results were distributed as follows. The high level of persistence was diagnosed in 36 students, the average one in 71 students, and the low one in 73 respondents.

The results of the experiment allowed distributing the respondents into three groups according to the level of their persistence manifestation.

At the next stage the results of the judgments test of persistence, the paper-and-pencil test of persistence and the author's questionnaire on persistence were analyzed. In the analysis of the author's self-assessment questionnaire on persistence, the results showed the similarity with the experimental data in the levels of persistence. The results obtained by the A. I. Krupnov methods showed the identity of indicators' manifestation.

By comparison, to the experiment data it was found out that the highest indicators, on harmonious variables of persistence characterizing the success of the manifestation of this personality trait were recorded in the respondents conditionally allocated to a group with a high level of development of the given property. The highest indicators of the disharmonic characteristics were found in the respondents included into the group with the low levels of persistence on the provisional basis.

To confirm the groups of subjects, provisionally selected according to the levels of persistence manifestation, we conducted a cluster analysis of indicators. According to the cluster analysis results, the validity of the provisional selecting of the above - mentioned groups of subjects was proved. Thus, the sample comprising 200 people was distributed as follows. The first cluster included 46 people, the second -89 , and the third -65 people. The results of dispersions' comparison acted as the factor proving the homogeneity and specificity of each of the clusters.

To define the differences identified in different groups a comparative analysis using the Student's t-criterion was conducted among the bipolar variables in each component of persistence.

Thus, in the first cluster relating to the high level of persistence, there were established the valid distinctions between such indicators as: the ergicity in the dynamic component significantly exceeds aergicity $(\mathrm{p}<.01)$; in the regulatory component the variable of internality quantitatively dominates the externality $(\mathrm{p}<.01)$; the sthenic emotions are more expressed than the asthenic $(\mathrm{p}<.05)$; and in the cognitive component the meaningfulness surpasses the awareness $(p<.05)($ Table 1$)$.

Table 1. Comparative analysis of average values of variables for respondents with a high level of persistence $(n=46)$

\begin{tabular}{|c|c|c|c|c|c|c|c|c|c|c|c|c|c|c|}
\hline Variables & $\begin{array}{l}\text { Soci- } \\
\text { ally } \\
\text { Signi- } \\
\text { ficant } \\
\text { ?urposes } \\
\end{array}$ & $\begin{array}{c}\text { Perso- } \\
\text { nally } \\
\text { Significant } \\
\text { Purpo-ses }\end{array}$ & Ergicity & Aergicity & $\begin{array}{c}\text { Sthenic } \\
\text { Emotions } \\
\text { (sthenicity) }\end{array}$ & $\begin{array}{l}\text { Asthenic } \\
\text { Emotions } \\
\text { (asthenicity }\end{array}$ & $\begin{array}{c}\text { Internal } \\
\text { Regulation } \\
\text { (internality) }\end{array}$ & $\begin{array}{c}\text { External } \\
\text { Regulation } \\
\text { (externality) }\end{array}$ & $\begin{array}{l}\text { Sociocentric } \\
\text { Motivation }\end{array}$ & $\begin{array}{l}\text { Egocentric } \\
\text { Motivation }\end{array}$ & $\begin{array}{l}\text { Profound } \\
\text { Awareness }\end{array}$ & $\begin{array}{l}\text { Superficial } \\
\text { Awareness }\end{array}$ & Objectness & Subjectness \\
\hline & 21.8 & 20 & 36,0 & 16.0 & 27.0 & 22.0 & 35.0 & 20.0 & 7.7 & 9.3 & 32 & 28 & 29.1 & 28.9 \\
\hline Differences & \multicolumn{2}{|r|}{1.8} & \multicolumn{2}{|r|}{20} & \multicolumn{2}{|r|}{5} & \multicolumn{2}{|c|}{15} & \multicolumn{2}{|c|}{-1.6} & \multicolumn{2}{|c|}{4} & \multicolumn{2}{|c|}{0.2} \\
\hline t-Criterium & \multicolumn{2}{|r|}{1.04} & \multicolumn{2}{|c|}{6.68} & \multicolumn{2}{|c|}{2.55} & \multicolumn{2}{|c|}{5.49} & \multicolumn{2}{|c|}{.49} & \multicolumn{2}{|c|}{2.41} & \multicolumn{2}{|c|}{.08} \\
\hline $\begin{array}{c}\text { P- Significance } \\
\text { level } \\
\text { (Sig.) }\end{array}$ & \multicolumn{2}{|r|}{ - } & \multicolumn{2}{|r|}{.01} & \multicolumn{2}{|c|}{.05} & \multicolumn{2}{|c|}{.01} & \multicolumn{2}{|l|}{-} & \multicolumn{2}{|c|}{.05} & \multicolumn{2}{|r|}{ - } \\
\hline
\end{tabular}


The second cluster concerning the average level of persistence also contains a number of statistically significant differences among the characteristics inside the components. In the instrumentally-stylistic characteristics, the ergicity is expressed greater than the aergicity $(\mathrm{p}<.01)$; astenicity dominates over stenicity $(\mathrm{p}<.05)$; externality surpasses internal- ity $(p>.01)$. In the motivationally-meaningful unit, the personally-significant purposes for persistence essentially surpass the sociallysignificant $(\mathrm{p}<.01)$, and in the productive component the personally-significant productivity surpasses the object-communicative $(p<.05)$, the distinctions were not detected in other components (table 2).

Table 2. Comparative analysis of the values of variables for respondents with an average level of persistence $(n=89)$

\begin{tabular}{|c|c|c|c|c|c|c|c|c|c|c|c|c|c|c|}
\hline Variables & $\begin{array}{c}\text { Socially } \\
\text { Signif- } \\
\text { icant } \\
\text { Purpo- } \\
\text { ses }\end{array}$ & $\begin{array}{l}\text { Person- } \\
\text { ally } \\
\text { Signifi- } \\
\text { cant } \\
\text { Purposes }\end{array}$ & $\begin{array}{l}\text { Ergi- } \\
\text { cy }\end{array}$ & $\begin{array}{l}\text { Aer- } \\
\text { gicity }\end{array}$ & $\begin{array}{l}\text { Sthenic } \\
\text { Emoti-ons } \\
\text { (sthen- } \\
\text { icity) }\end{array}$ & $\begin{array}{l}\text { Asth-enic } \\
\text { Emot-ions } \\
\text { (asthen- } \\
\text { icity) }\end{array}$ & $\begin{array}{c}\text { Internal } \\
\text { Regu- } \\
\text { lation } \\
\text { (inter- } \\
\text { nality) }\end{array}$ & $\begin{array}{l}\text { External } \\
\text { Regul-ation } \\
\text { (exter- } \\
\text { nality) }\end{array}$ & $\begin{array}{l}\text { Socioce- } \\
\text { ntric } \\
\text { Motiv- } \\
\text { ation }\end{array}$ & $\begin{array}{c}\text { Egocen- } \\
\text { tric } \\
\text { Motiva- } \\
\text { tion }\end{array}$ & $\begin{array}{l}\text { Profo- } \\
\text { und } \\
\text { Awar- } \\
\text { eness }\end{array}$ & $\begin{array}{c}\text { Supe- } \\
\text { rficial } \\
\text { Aware- } \\
\text { ness }\end{array}$ & $\begin{array}{l}\text { Objec- } \\
\text { tness }\end{array}$ & $\begin{array}{c}\text { Subjec- } \\
\text { tness }\end{array}$ \\
\hline & 10.1 & 15.8 & 34 & 21 & 10.9 & 15.8 & 23.0 & 29.0 & 30.1 & 29.2 & 34.7 & 33.1 & 7.7 & 12.5 \\
\hline Differences & \multicolumn{2}{|r|}{-5.7} & \multicolumn{2}{|c|}{13} & \multicolumn{2}{|c|}{-4.9} & \multicolumn{2}{|r|}{-6.0} & \multicolumn{2}{|c|}{9} & \multicolumn{2}{|c|}{1.6} & \multicolumn{2}{|c|}{-4.8} \\
\hline $\mathrm{t}$ - Criterium & \multicolumn{2}{|r|}{2.7} & \multicolumn{2}{|c|}{4.54} & \multicolumn{2}{|c|}{2.22} & \multicolumn{2}{|c|}{2.72} & \multicolumn{2}{|c|}{.14} & \multicolumn{2}{|c|}{1.04} & \multicolumn{2}{|c|}{2.12} \\
\hline $\begin{array}{l}\text { P- Signif- } \\
\text { icance level } \\
\text { (Sig.) }\end{array}$ & \multicolumn{2}{|r|}{.01} & \multicolumn{2}{|c|}{.01} & \multicolumn{2}{|c|}{.05} & \multicolumn{2}{|r|}{.01} & \multicolumn{2}{|r|}{ - } & \multicolumn{2}{|r|}{ - } & \multicolumn{2}{|r|}{.05} \\
\hline
\end{tabular}

In the third cluster, corresponding to the low level of persistence the dominant role belongs mostly to the disharmonious variables. Thus, in the dynamic component, aergicity exceeds ergicity at a statistically significant level $(\mathrm{p}<.01)$; in the emotional component, the asthenic emotions dominate over the sthenic $(\mathrm{p}<.01)$; in the regulatory, the external locus of control significantly exceeds internality $(p<.05)$; in the cognitive component, the awareness significantly exceeds the meaningfulness $(\mathrm{p}<.01)($ Table 3$)$.

Table 3. Comparative analysis of average values of variables in respondents with a low level of perseverance $(n=65)$

\begin{tabular}{|c|c|c|c|c|c|c|c|c|c|c|c|c|c|c|}
\hline Variables & $\begin{array}{c}\text { Socia- } \\
\text { lly } \\
\text { Signif- } \\
\text { icant } \\
\text { Purp- } \\
\text { oses }\end{array}$ & $\begin{array}{l}\text { Persona- } \\
\text { lly } \\
\text { Signifi- } \\
\text { cant } \\
\text { Purposes }\end{array}$ & Ergicity & Aergicity & $\begin{array}{l}\text { Sthenic } \\
\text { Emotions } \\
\text { (sthenicity) }\end{array}$ & $\begin{array}{c}\text { Asthenic } \\
\text { Emotions } \\
\text { (asthenicity }\end{array}$ & $\begin{array}{c}\text { Internal } \\
\text { Regulation } \\
\text { (internality) }\end{array}$ & $\begin{array}{l}\text { External } \\
\text { Regulation } \\
\text { (externality) }\end{array}$ & $\begin{array}{l}\text { Sociocentric } \\
\text { Motivation }\end{array}$ & $\begin{array}{l}\text { Egocentric } \\
\text { Motivation }\end{array}$ & $\begin{array}{l}\text { Profound } \\
\text { Awareness }\end{array}$ & $\begin{array}{l}\text { Superficial } \\
\text { Awareness }\end{array}$ & Objectness & Subjectness \\
\hline & 6.4 & 6.2 & 27.1 & 22.5 & 9.2 & 13.6 & 14.4 & 17.7 & 12.4 & 13.9 & 10.1 & 12.5 & 9.4 & 9.6 \\
\hline Differences & & .2 & & 4.6 & & 4.4 & & 3 & -1 & & & 2.4 & & -.2 \\
\hline $\mathrm{t}$-Criterium & & .06 & & .83 & & 78 & & 18 & 1.0 & & & .02 & & .10 \\
\hline $\begin{array}{c}\text { P- } \\
\text { Significance } \\
\text { level (Sig) }\end{array}$ & & - & & .01 & & 01 & & 5 & - & & & 05 & & - \\
\hline
\end{tabular}

The observed statistically significant distinctions within each of the components of persistence allow to consider the specificity of this personality trait manifestation according to one of the revealed types, describing the success or lack of success in persistent behavior.

\section{DISCUSSION}

The identified quantitative differences in different clusters characterize the levels of persistence manifestation. Judging by the dominance of the variables it is possible to assert that the first cluster includes the respon- dents with high levels of this trait manifestation. The second cluster is represented by the participants with an average level of the manifestation of the trait under discussion, and the third cluster accounted for the participants with low level of persistence.

The analysis of the hierarchical structure of the persistence variables in the respondents with low levels of manifestation of this quality allowed revealing the dominance in the instrumentally-stylistic block of such characteristics as asthenicity, aergicity and externality, and awareness in the motivationallymeaningful block. The revealed set of characteristics defines the mechanism of persistence manifestation, in this case it is its low level, 
due to the dominance of passivity and inertness of behavior, decrease in the emotional tone, weak internal self-regulation and an under-developed system of knowledge and skills of persistent behavior.

A distinctive feature of the manifestation of a high level of persistence in students is the divergent scope of targets, a wide range of incentive motives and the sphere of the implementation of persistence in the conditions of the expressed activity and variability of behavior, good self-regulation of persistent behavior and optimism.

The analysis results of the questionnaire "The personal self-assessment of self-realization" showed that self-realization as psychological formation can be adequately characterized by the respondents with a low level of perseverance. This gives you the opportunity to consider the phenomenon they demonstrate in more detail, using a Multidimensional questionnaire of personality self-realization.

Thus, the empirical results obtained by using this technique in the students with the low persistence level testify that the greatest quantitative indicators have such characteristics as inertia, pessimism, destructiveness, conservative attitude, personal and social barriers of self-realization. The level of expression of these characteristics is considered to be medium-high. In the second place, there are such parameters as activity, externality, selfcenteredness and constructiveness in their quantitative expression. The listed attributes correspond to the average level of expression.

The third group was comprised of the remaining attributes of self-realization: sociallycorporate purposes and personally-significant attitudes to self-realization, optimism, internal self-regulation, socio-centric motivation and creativity. All the noted attributes correspond to the low level of manifestation in their expressiveness degree. The distribution of the attributes of self-realization on the quantitative scale defines the significance of each parameter, in the mechanism of this phenomenon defining its specific conditionality. In the presented hierarchical model, the main functional load in the manifestation of self-realization is carried by the characteristics that are included in the first group.

We will comment on the given statement from the point of view of the qualitative analysis. Bearing in mind that the first group included only disharmonious characteristics it is necessary to assume their negative impact on the process of self-realization. Thus, inertness is a barrier to the manifestation of the person's activity, the students in this group are more likely to be passive, do not show initiative or purposefulness. Their activity appears only in the compelled situations. Moreover, it is aggravated by their pessimistic mood. They are too unconfident of their possibilities and capabilities, are guided more often by failure and do not believe in the success. Probably considerable social and personal barriers cause such behavior. On the one hand, they have a limited behavioral resource for self-realization, do not have the behavioral flexibility and variability, they do not possess good communicative and social skills. These are the roots of their dominating conservatism. Yet, on the other hand, they have a lot of personality complexes - lack of confidence, shyness, anxiety, etc. All this together, most likely, leads to the self-destructive outcome of their self-realization.

In the psychological structure of selfrealization revealed by means of the correlation and factor analysis, we found out that the core constructs are inertia, destructiveness, personal and social barriers that determine the specificity of this phenomenon.

In general, it is possible to ascertain that the respondents with the low persistence level experience considerable difficulties in fullscale self-realization, due to the imbalance in the structure of the individual characteristics in the structure of the given phenomenon. First of all, it concerns the motivational, cognitive and instrumental parameters.

The analyses of the questioner "Personal self-realization self-estimation" helped to conclude that in the students with a high level of persistence have a profound knowledge of the self-realization phenomenon, imagine the main space for the successful self-realization and give a high assessment of their self-realization level in different spheres of life.

The results received with the multidimensional questionnaire of personality selfrealization, show that the most expressed in the quantitative equivalent are such indicators as creativity, activity, socially-significant and egocentric motives. The quantitative indicator of these characteristics corresponds to a high level of expressiveness. Internality, constructiveness, optimism, and personally-significant intentions are located at the mid-high level of the expressiveness. Socially-corporate intentions, conservatism and externality are situated at the average level. Finally, the last group with the low level of manifestation is represented by inertia, pessimism, destructiveness, personal and social barriers of self-realization 
manifestation.

On the contents side, the presented hierarchy of structural indicators of self-realization expressiveness testifies that the respondents prove themselves in everyday life in different spheres of society very intensively. The students with the high persistence level tend to be involved in all the activities and actions, constantly take the initiative, and at times are organizers in the general mass kinds of activity, initiating associates to participate. They apply different methods and techniques of self-expression, showing flexibility and plasticity of behavior. In many different situations, they take into account the external factors and their own possibilities on the basis of which, they implement certain schemes of their self-realization.

Moreover, these respondents record a very high level of motivation to self-expression. It is noteworthy that their motivation has a wide range from the purely personal motives, providing the satisfaction of their egoistical requirements, for example, connected with the increase of material incentives, or career advancement, to socially-significant ones, providing the solution of general socially important issues by means of self-expression.

Besides, it is possible to see that these respondents are distinguished by the expressed internal locus of control at self-realization. In most cases, they rely exclusively on their own internal resources and hardly take into account the external circumstances, any factors and other people's opinions. In the process of self-realization the respondents are driven by their optimism, the anticipation of positive results, they feel confidence in their actions and behavior and predict extremely favorable outcome of their activities. Thanks to their high activity, self-control, intelligent actions, the expressed motivation and optimism the respondents have good indicators on the success of their self-realization, as it is indicated by their constructiveness.

Thus, the hierarchical analysis of the self-realization characteristics allows ascertaining sufficient success of self-realization of students with a high level of persistence.

The activity, creativity and optimistic attitude act as the backbone characteristics providing stable relations with other parameters in the psychological structure of self-realization of the respondents.

This feature set provides the high efficiency of the process of the respondents' selfexpression. The results of the factor analysis confirmed the initial data obtained by means of the hierarchical and correlation analysis of the empirical findings.

Thus, the quantitative and qualitative analysis of self-realization of students with a high level of persistence testifies that they are quite satisfied with the results of their selfrealization. They have a wide space for selfexpression in educational and professional activities, family relationships and social communities. Their self-realization is characterized by a high activity in different life spaces, positive emotionally-conative regulation of their behavior, activity and communication and non-standard, original ways and methods of self-expression.

\section{CONCLUSION}

The conducted empirical research has allowed to confirm the viability of the put forward assumption that self-realization is a multidimensional psychological formation determined by a complex of external and internal factors, providing the success of the individual self-expression in different spheres of life in the process of ontogenesis. It has allowed establishing that one of the factors influencing the success of self-realization is persistence as a basic trait of the person.

The obtained data specifies that the high level of persistence manifestation provides successful self-realization of the person while the low level of the development of this quality does not promote a full-scale self-realization of students in different spheres of life.

The received empirical data on the impact of persistence on the self-realization of the person will allow developing the effective complex programs promoting the optimization, both of the persistence and of the selfrealization of the person.

\section{ACKNOWLEDGMENTS}

The article is made in the framework of the initiative of NIR No. 050421-0-000 "Self-realization of personality in multicultural Wednesday", performed on the basis of social and differential psychology department of Peoples' Friendship University of Russia (RUDN University).

\section{Conflict of interests}

The authors declare no conflict of interest. 


\section{REFERENCES}

Ashton, M. C., \& Lee, K. (2001). A theoretical basis for the major dimensions of personality. European Journal of Personality, 15(5), 327-353. doi: $10.1002 /$ per.417

Boekaerts, M. (1996). Self-regulated learning at the junction of cognition and motivation. European psychologist, 1(2), 100-112. https://doi. org/10.1027/1016-9040.1.2.100

Butler, J. C. (2000). Personality and emotional correlates of right-wing authoritarianism. Social Behavior and Personality: an international journal, 28(1), 1-14. https://doi.org/10.2224/ sbp.2000.28.1.1

Chamorro-Premuzic, T., Furnham, A., \& Ackerman, P. L. (2006). Ability and personality correlates of general knowledge. Personality and Individual Differences, 41(3), 419-429. https://doi. org/10.1016/j.paid.2005.11.036

Cheng, H., \& Furnham, A. (2003). Personality, selfesteem, and demographic predictions of happiness and depression. Personality and individual differences, 34(6), 921-942. https://doi. org/10.1016/S0191-8869(02)00078-8

Cheung, F. M., van de Vijver, F. J., \& Leong, F. T. (2011). Toward a new approach to the study of personality in culture. American Psychologist, 66(7), 593. http://dx.doi.org/10.1037/a0022389

Dweck, C. S. (2000). Self-theories: Their role in motivation, personality, and development. Psychology Press. https://goo.gl/mozQJ5

Hakimi, S., Hejazi, E., \& Lavasani, M. G. (2011). The relationships between personality traits and students' academic achievement. Procedia-Social and Behavioral Sciences, 29, 836-845. https:// doi.org/10.1016/j.sbspro.2011.11.312

Korostyleva, L. A. (2005). Psikhologiya samorealizatsii lichnosti: zatrudneniya v profes-sional'noy sfere [The psychology of self-realization: The difficulties in the profession-tional sphere]. St. Petersburg: Rech.

Krupnov, A. I. (2006). The system-dispositional approach to studying the personality and its properties. Bulletin of Peoples' Friendship University of Russia.- Series: Psychology and Pedagogycs, 1, 63-73. https://elibrary.ru/item. asp?id=9926464

Krupnov, A.I., Novikova, I.A. \& Kozhukhova, Y.V. (2013). Sistem-Functional Model of Personality Traits. Academic Journal of Interdisciplinary Studies, 2(9), 407-413. doi:10.5901/ajis.2013. v2n9p407

Kudinov, S.I. \& Kudinov, S.S. (2011). Psychological Self-Actualization analysis of the Russian and Foreign Students. Bulletin of Peoples' Friendship University of Russia.- Series: Psychology and Pedagogycs, 5, 72-79. http://journals.rudn. $\mathrm{ru} / \mathrm{psychology-pedagogics/article/view/7929;}$ https://elibrary.ru/item.asp?id=20290088

Kudinov, S.I., Krupnov, A.I. \& Kudinov, S.S. (2012). Self-Actualization of Personality as Precondition of Manifestation of Interethnic Tolerance in the Former Soviet Union. Bulletin of Peoples' Friendship University of Russia. - Series: Psychology and Pedagogycs, 1, 5-13. http://journals.rudn.ru/psychology-pedagogics/ article/view/7981; https://elibrary.ru/item. asp?id=17560721
Kudinov, S.I. (2013). Individually-Typological Peculiarities of Personality Self-Discipline and Self-Actualization Correlation. Bulletin of Peoples' Friendship University of Russia. - Series: Psychology and Pedagogycs, 2, 14-19. http://journals.rudn.ru/psychology-pedagogics/ article/view/7746; https://elibrary.ru/item. asp? $\mathrm{id}=19091040$

Kudinov, S. I., Kudinov, S. S., Mikhailova, O. B. \& Ruchina, M. A. (2015). Self-realization of a personality: theoretical and empirical research: Monograph, Moscow, 210. https://elibrary.ru/ item.asp? $\mathrm{id}=25158392$

Maslow, A. H (1968). Toward a psychology of beind. New York, 360.

Maslow, A. H. (1954). Motivation and Personality. New York, Harpaer \& Row, 334.

Mikhailova, O. B., Kudinov, S. I., \& Jerez, K. G. M. (2015). Value-Motivational Characteristics of Innovativeness as Prospects for Successful SelfFulfillment. Mediterranean Journal of Social Sciences, 6(3 S2), 105. doi:10.5901/mjss.2015. v6n3s 2 p 105

Mikhailova, O. B. (2015). The value-motivational structure of the innovativeness young students. Psychology in Russia: State of the Art. 8(1), 112-124. doi:10.11621/pir.2015.0110

Myers, D. G. (1992). The secrets of happiness. Psychology Today, 25, 38-45. https://elibrary.ru/item. asp? $\mathrm{id}=8779580$

Novikova, I. A. \& Zamaldinova, G. N. (2010). Selfconfidence of personality and the level of selfactualization of the employees of commercial organizations. Bulletin of Peoples' Friendship University of Russia. - Series: Psychology and Pedagogycs, 2, 21-26. http://journals.rudn. $\mathrm{ru} /$ psychology-pedagogics/article/view/8198; https://elibrary.ru/item.asp?id=15114471

Novikova, I. A., Shlyakhta, D. A. \& Baranova, S. V. (2013). Relations of Individually-Typical Features of Persistence with Temperament Properties in Students. Bulletin of Peoples' Friendship University of Russia. - Series: Psychology and Pedagogycs, 3, 22-30. http://journals.rudn. ru/psychology-pedagogics/article/view/7800; https://elibrary.ru/item.asp?id=20290122

Stee, 1 P., Schmidt, J. \& Shultz, J. (2008). Refining the relationship between personality and Subjective well-being Psychological Bulletin, 34, 138-161. https://prism.ucalgary.ca/jspui/bitstream/1880/47915/1/Steel Psychological Bulletin_2008_Postprint.pdf

Zhang, Ten (2013). Relative performance characteristics of self-i chinese men and women. Akmeologiya, 4 (48), 122-126. https://elibrary.ru/ item.asp? $\mathrm{id}=20305062$ 